The Geneva Papers on Risk and Insurance, 15 (No. 57, October 1990), 399 - 401

\title{
The Use of Ecu in Insurance Contracts in Italy
}

\author{
by Fabio Padoa*
}

1. The ideal world for an international insurer or reinsurer would be one with one single currency, acceptable everywhere and of a constant value. The three functions of a perfect currency would be thus fulfilled, namely an accurate measure of values, an economic values reservoir and a universally accepted means of exchange. The insurer carries out fully his function when he can substitute losses of values with equivalent values, or when in Life Assurance he pays the amount convened when the policy was taken out, in short when he can exchange values for values. But values at risk are expressed in money and in money are claims and maturities paid. Also investments meant to safeguard the value of premiums collected are necessarily kept in money. The insurer does not exchange therefore value for value but money for money.

But the international spread of risks makes it necessary to estimate original values in currencies, the reciprocal ratios of which are variable: identical technical results often produce different financial results; according to the currency used by a Company in its balance sheet. As a result the international insurer must add to his insurance risk, one of a completely different nature, size and imponderability: the rate-of-exchange risk.

As a far as time is concerned we all know that insurance operations are not instantaneous. Between the time that the premium is advanced, the claim, maturity and settlement, several years may go by, lengthened even further for reinsurers by delays in bookkeeping procedures. In the meantime the continuity of operations must be guaranteed by underwriting reserves wisely invested, but this continuity is hindered by the deterioration of values made often more cumbersom by the legal obligation to invest in bonds subject to devaluation. Here again the risk of inflation - an improper one - must be added to the insurance risk.

The main concern of the insurer is therefore to undertake his commitments (and guarantee them with congruent assets) in a currency or a near-currency as stable as possible, and such is certainly the Ecu if compared to the single national currencies, even the soundest. But in order to choose the Ecu as the proper currency for an insurance contract, both insurer and insured must be of the same idea, the latter recognizing his advantages in choosing the European monetary yardstick. The two arguments in favour of the Ecu for both are: Ecu's relative stability and its multinational character.

\footnotetext{
* Director, Generali, Trieste.
} 
2. The more likely candidates for a contract stipulated in Ecu are :

\subsection{In life assurance}

- Individual policy holders of countries with currencies more subject to devaluation, who can recognize in Ecu a more reliable coverage.

- Multinational companies interested in Employee Benefits coverages for their mobile personnel, those still in active service and pensioners.

- Financial intermediaries issuing coverages likewise effective in the countries of their international customers.

\subsection{In non-life insurance}

- International organizations such as the EEC, the European Space Agency and others, operating on a worldwide basis.

- Operators, also domestic (such as hotel and tour agencies, firms with third party liability in foreign countries, etc.), having international customers to indemnify in case of particular events.

- Multinational firms with balance sheets and book-keeping in Ecu such as St. Gobain, or UNAT, the European Insurance Company of the AIU Group.

\subsection{In reinsurance}

- Reinsurers not knowing in which currency they will have to meet major catastrophies.

- Ceding companies seeking securities with coverage limits protected against currency fluctuations.

- Insurance groups wishing to balance cessions of their various international branches and subsidiaries.

Of these nine potential customer groups, those that so far have used to the greatest extent the Ecu are Italian Life Assurance individual policy holders.

Life assurance in Italy, until recently, was not in great demand, and this for a number of reasons, including the devaluation of the lira after the two world wars. In 1987 of the total premiums collected in Italy, only $21.6 \%$ originated from life assurance against the $44.7 \%$ in Germany and the $66 \%$ in Great Britain. Today, thanks to policies with profit sharing clauses or linked to investment funds, values are reasonably safe, and in fact the growth rate of life assurances has been considerable during recent years, namely 25 to $30 \%$ per annum.

However there is still some distrust of policies issued in Italian lire, hence the success of policies in Ecu, which have been offered since 1982 by Generali, the leading Italian insurance company. Failing recurring bond issues in Ecu up to 1985, only single premium policies were sold, but since 1986 the issues of public and private bonds in Ecu became quite common, and a yearly premium endowment policy linked with an Ecu fund, was launched under the name of "Europea". Also this one has been well accepted and has registered an even higher growth trend than the quite high one of other revaluable policies. In comparison to the Company's total output, policies issued in Ecu registered a growth of $4.9 \%$, $6.3 \%, 9.5 \%$ and $16.1 \%$ during the period 1986 to August 1989 . 
The average capital insured was higher than that of other revaluable policies, proving that this product appeals to customers of a higher level. A research showed that only a limited number of brokers and agents sold this policy, those who better understood it and were able to promote it successfully.

Also fairly popular are life assurance policies issued in Ecus to holders of the American Express credit card. A thorough action to sell Employee Benefits coverages in Ecus has not yet been carried out.

Subsequently other Italian insurance companies have introduced policies similar to those of Generali; so that now life policies in Ecus are available on the entire Italian market.

Generali have also tried to export this type of policy to other European markets, and found a fairly promising ground in Spain and Greece, while problems arose in countries with strong currencies such as Holland.

As far as non-life insurance is concerned, Generali launched a policy named Ecu-Hotel which provides for the hotel trade, an indemnity for the loss of profits caused by the interruption of activities due to fire, natural calamities, epidemics, mass food poisoning etc. It seems to find growing favour with the hotel trade.

In Space Risks insurance, coverages issued in Ecus simplify the distribution of risks between the various markets, and this explains their success.

But the same cannot be said for Marine Insurance; more bound to traditional usages which priviledge more common international currencies such as the dollar.

In conclusion one can say that

a) Insurance in general has a great interest in a stable and common currency;

b) the current Ecu basket is already close to the model which will be completed when it will be recognized as an official means of payment and will enjoy fixed parity with all other national currencies, thus becoming a "real" currency;

c) this goal will be attained when the private use of the Ecu in its present form will grow, since for currency as for all other things it is the market that decides. Therefore insurers have an important task to perform: to encourage through exhaustive information and systematic advertising the widespread use of the Ecu. In this the basic interest of our industry coincides with that of our customers. Few business activities have as ours, daily contacts with millions of customers, and can impress upon public opinion, and in particular savers and international operators, the worth of the Ecu.

Those who, like myself, see in the European Union a fundamental guaranty for our and the next generation, especially in view of the recent developments in Eastern Europe discern in the work of insurers favourable to the Ecu, a significant contribution towards its realization. 